\title{
Antihyperlipidemic and antiperoxidative effect of Diasulin, a polyherbal formulation in alloxan induced hyperglycemic rats Ramalingam Saravanan and Leelavinothan Pari*
}

\author{
Address: Department of Biochemistry, Faculty of Science, Annamalai University, Annamalai Nagar, Tamil Nadu - 608 002, India \\ Email: Ramalingam Saravanan - saranbio@rediffmail.com; Leelavinothan Pari* - paribala@sancharnet.in \\ * Corresponding author
}

Published: 22 June 2005

BMC Complementary and Alternative Medicine 2005, 5:14 doi:10.1 186/1472-

$6882-5-14$

This article is available from: http://www.biomedcentral.com/I472-6882/5/I4

(c) 2005 Saravanan and Pari; licensee BioMed Central Ltd.

This is an Open Access article distributed under the terms of the Creative Commons Attribution License (http://creativecommons.org/licenses/by/2.0), which permits unrestricted use, distribution, and reproduction in any medium, provided the original work is properly cited.

\begin{abstract}
Background: This study was undertaken to investigation the effect of Diasulin, a poly herbal drug composed of ethanolic extract of ten medicinal plants on blood glucose, plasma insulin, tissue lipid profile, and lipidperoxidation in alloxan induced diabetes.

Methods: Ethanolic extract of Diasulin a, poly herbal drug was administered orally $(200 \mathrm{mg} / \mathrm{kg}$ body weight) for 30 days. The different doses of Diasulin on blood glucose and plasma insulin in diabetic rats were studied and the levels of lipid peroxides [TBARS, and Hydroperoxide] and tissue lipids [cholesterol, triglyceride, phospholipides and free fatty acids] were also estimated in alloxan induced diabetic rats. The effects were compared with glibenclamide.

Result: Treatment with Diasulin and glibenclamide resulted in a significant reduction of blood glucose and increase in plasma insulin. Diasulin also resulted in a significant decrease in tissue lipids and lipid peroxide formation. The effect produced by Diasulin was comparable with that of glibenclamide.
\end{abstract}

Conclusion: The decreased lipid peroxides and tissue lipids clearly showed the antihyperlipidemic and antiperoxidative effect of Diasulin apart from its antidiabetic effect.

\section{Background}

Diabetes mellitus is syndrome, initially characterized by a loss of glucose homeostasis resulting from defects in insulin secretion, insulin action both resulting impaired metabolism of glucose and other energy- yielding fuels such as lipids and protein [1]. Experimental diabetes in animals has provided considerable insight into the physiologic and biochemical derangement of the diabetic state. Many of the derangement have been characterized in hyperglycemic animals. Significant changes in lipid metabolism and structure also occur in diabetes [2]. In these cases the structural changes are clearly oxidative in nature and are associated with development of vascular disease in diabetes [3]. In diabetic rats, increased lipidperoxidation was also associated with hyperlipidemia [4]. Liver, an insulin dependent tissue that plays a pivotal role in glucose and lipid homeostasis and it is severely affected during diabetes [5]. Liver and kidney participates in the uptake, oxidation and metabolic conversion of free fatty acids, synthesis of cholesterol, phospholipids, and triglycerides. During diabetes, a profound alteration in the concentration and composition of lipids occurs. 
Table I: Diasulin (Composition and concentration)

\begin{tabular}{|c|c|c|c|c|c|}
\hline SI. No & Botanical name & Common name & Family & Part used & $\begin{array}{c}\text { Concentration } \\
\text { (mg/dL) }\end{array}$ \\
\hline I & Cassia auriculata & Tanner's cassia & Ceasalpinaceae & Flower & 40 \\
\hline 2 & Coccinia indica & Little gourd & Cucurbitaceae & Fruit & 40 \\
\hline 3 & Curcuma longa & Turmeric & Zingiberaceae & Rhizome & 40 \\
\hline 4 & Emblica officinalis & Indian gooseberry & Euphorbiaceae & Fruit & 20 \\
\hline 5 & Gymnema sylvestre & Ram's horn & Asclepiadaceae & Leaves & 20 \\
\hline 6 & Momordica charantia & Bitter gourd & Cucurbitaceae & Fruit & 30 \\
\hline 7 & Scoparia dulcis & Sweet broom weed & Scrophulariaceae & Whole Plant & 40 \\
\hline 8 & Syzigium cumini & Jamun & Myrtaceae & Seed & 20 \\
\hline 9 & Tinospora cardifolia & Gulancha tinospora & Menispermaceae & Root & 20 \\
\hline 10 & $\begin{array}{l}\text { Trigonella foenum } \\
\text { graecum }\end{array}$ & Fenugreek & Fabaceae & Seed & 50 \\
\hline
\end{tabular}

Despite the great strides that have been made in the understanding and management of diabetes, the disease and disease related complications are increasing unabated [6]. Inspite of the presence of known antidiabetic medicine in the pharmaceutical market, remedies from medicinal plants are used with success to treat this disease [7]. Many traditional plant treatments for diabetes are used throughout the world. Plant drugs [8] and herbal formulation [9-11] are frequently considered to be less toxic and more free from side effects than synthetic one. Based on the WHO recommendations hypoglycemic agents of plant origin used in traditional medicine are important [12]. The attributed antihyperglycemic effects of these plants is due to their ability to restore the function of pancreatic tissues by causing an increase in insulin output or inhibit the intestinal absorption of glucose or to the facilitation of metabolites in insulin dependent processes. Hence treatment with herbal drugs has an effect on protecting $\beta$-cells and smoothing out fluctuation in glucose levels $[13,14]$. In general, there is very little biological knowledge on the specific modes of action in the treatment of diabetes, but most of the plants have been found to contain substances like glycosides, alkaloids, terpenoids, flavonoids etc., that are frequently implicated as having antidiabetic effects [15]. In the traditional system of Indian medicine, plant formulation and combined extracts of plants are used as drug of choice rather than individual. Various herbal formulations such as diamed [16], coagent db [17] and hyponidd [18], are well known for their antidiabetic effects. Diasulin is a poly herbal drug composed of ten medicinal plants (Table 1), which are already reported for their antidiabetic activity. In our previous study, we have demonstrated the antidiabetic effect of Diasulin in alloxan diabetic rats [19]. The present investigation was undertaken to study the effect of the potential antidiabetic herbal formulation, Diasulin on lipidperoxidation and tissue lipid profile in alloxan diabetic rats. The effects produced by this drug on different parameters were compared with glibenclamide, a reference drug.

\section{Methods}

\section{Experimental animals}

Male Wistar rats of body wt. 180-200 g were obtained from central Animal House, Raja Muthiah Medical College, Annamalai University. The animals were fed on standard pellet diet (Hindustan Lever, Mumbai, India) and water ad libitum. The rats used in the present study were maintained in accordance with guidelines of the National Institute of Nutrition, Indian Council of Medical Research, Hyderbad, India and the study approved by the ethical committee (Vide No: 88, 2002).

\section{Drug and chemicals}

Ethanolic extract of ten medicinal plants, which are involved in preparation of Diasulin, was a gift from herbal remedies, Pondicherry, India.

The residual extracts of the antidiabetic plants were mixed and named as Diasulin was prepared (Table 1) on the basis of an ayurvedic antidiabetic formulation proposed by Pandey et al. (1995) [20]. $500 \mathrm{~g}$ of each plant (chopped into small pieces) was extracted individually were, soaked overnight in 1.5 litres of $95 \%$ ethanol. This suspension was filtered and the residue was resuspended in an equal volume of $95 \%$ ethanol for $48 \mathrm{~h}$ and filtered again. The two filtrates were pooled and the solvents were evaporated in a rotavapor at $40^{\circ}-50^{\circ} \mathrm{C}$ under reduced pressure and lyophilized. Alloxan monohydrate was purchased from BDH Chemicals, Poole, England. Enzyme linked immunosorbant assay (ELISA) kit for insulin assay was purchased from Boehringer Mannheim, Germany. All other biochemicals used in this experiment were purchased from Sigma Chemical Company Inc., St Louis, Mo, and USA. The chemicals were analytical grade. 


\section{Drug administration}

Diasulin was suspended in distilled water and administered orally through intragastric tube at the following doses of 50, 100 and 200-mg/kg body weight.

\section{Experimental induction of diabetes in rats}

The rats were injected intraperitoneally with alloxan monohydrate dissolved in sterile normal saline at a dose of $150 \mathrm{mg} / \mathrm{kg}$ body wt [21]. After 2 weeks, rats with moderate diabetes having glycosuria (indicated by Benedict's qualitative test) and hyperglycemia (i.e. with a blood glucose of $200-300 \mathrm{mg} / \mathrm{dl}$ ) were used for the experiment.

\section{Experimental design}

In the experiment, a total of 42 rats (30 diabetic surviving rats, 12 normal rats) were used. The rats were divided into seven groups of six rats each after the induction of alloxan diabetes. Group1: Normal treated rats. Group2: Normal rats given aqueous solution of Diasulin $(200 \mathrm{mg} / \mathrm{kg}$ body weight) daily using an intragastric tube for 30 days. Group 3: Diabetic control rats. Group 4: Diabetic rats given aqueous solution of Diasulin ( $50 \mathrm{mg} / \mathrm{kg}$ body weight) daily using an intragastric tube for 30 days. Group 5: Diabetic rats given aqueous solution of Diasulin $(100 \mathrm{mg} / \mathrm{kg}$ body weight) daily using an intragastric tube for 30 days. Group 6: Diabetic rats given aqueous solution of Diasulin (200 $\mathrm{mg} / \mathrm{kg}$ body weight) daily using an intragastric tube for 30 days. Group 7: Diabetic rats given aqueous solution of glibenclamide (600 $\mu \mathrm{g} / \mathrm{kg}$ body weight) daily using an intragastric tube for 30 days.

At the end of 30 days, all the rats were killed by decapitation under pentobarbitone sodium $(60 \mathrm{mg} / \mathrm{kg})$ anaesthesia. Blood was collected in tubes containing potassium oxalate and sodium fluoride solution for the estimation of blood glucose and plasma was separated for the assay of insulin. Liver and kidney were immediately dissected out, washed in ice-cold saline to remove the blood. The tissues were weighed and $10 \%$ tissue homogenate was prepared with $0.025 \mathrm{M}$ Tris - Hcl buffer, $\mathrm{pH}$ 7.5. After centrifugation at $200 \mathrm{rpm}$ for $10 \mathrm{~min}$, the clear supernatant was used to measure thiobarbituric acid reactive substances (TBARS) and hydroperoxides. For the determinations of lipids the liver and kidney tissues were weighed and lipids were extracted from tissues by the method of Folch et al [22] using chloroform - methanol mixture $\left(\mathrm{CHCl}_{3}\right.$ : $\mathrm{MeOH})(2: 1 \mathrm{v} / \mathrm{v})$.

\section{Biochemical analysis \\ Estimation of blood glucose and plasma insulin}

Blood glucose was determined by the O-toluidine method [23]. Plasma insulin was assayed by ELISA, using Boeheringer- Mannheim Kit with a Boeheringer analyser ES300.

\section{Estimation of lipid peroxidation}

Lipid peroxidation in liver and kidney were estimated colorimetrically by thiobarbituric acid reactive substances TBARS and hydroperoxides by the method of Niehius and Samuelsson [24] and Jiang et al. [25], respectively. In brief, $0.1 \mathrm{ml}$ of tissue homogenate (Tris-Hcl buffer, $\mathrm{pH}$ 7.5) was treated with $2 \mathrm{ml}$ of (1:1:1 ratio) TBA-TCA-HCl reagent (thiobarbituric acid $0.37 \%, 0.25 \mathrm{~N} \mathrm{HCl}$ and $15 \%$ TCA) and placed in water bath for $15 \mathrm{~min}$, cooled. The absorbance of clear supernatant was measured against reference blank at $535 \mathrm{~nm}$.

$0.1 \mathrm{ml}$ of tissue homogenate was treated with $0.9 \mathrm{ml}$ of Fox reagent ( $88 \mathrm{mg}$ butylated hydroxytoluene (BHT), 7.6 mg xylenol orange and $9.8 \mathrm{mg}$ ammonium ion sulphate were added to $90 \mathrm{ml}$ of methanol and $10 \mathrm{ml} 250 \mathrm{mM}$ sulphuric acid) and incubated at $37^{\circ} \mathrm{C}$ for $30 \mathrm{~min}$. The color developed was read at $560 \mathrm{~nm}$ colorimetrically. Hydroperoxides was expressed as mM/100 g tissue.

\section{Estimation of lipids}

Lipids were extracted from tissues by the method of Folch et al [22] using chloroform - methanol mixture $\left(\mathrm{CHCl}_{3}\right.$ : $\mathrm{MeOH})(2: 1 \mathrm{v} / \mathrm{v})$. The total cholesterol was estimated by the method of zlatkis et al [26]. To $0.1 \mathrm{ml}$ of the lipid extract, $9.9 \mathrm{ml}$ of ferric chloride-acetic acid reagent was added and allowed to stand for $15 \mathrm{~min}$ and then centrifuged. To $5 \mathrm{ml}$ of the supernatant, add $3 \mathrm{ml}$ of Conc. $\mathrm{H}_{2} \mathrm{So}_{4}$. The colour developed was read after $20 \mathrm{~min}$ at 560 $\mathrm{nm}$ against a reagent blank. Values were expressed as $\mathrm{mg} /$ $100 \mathrm{~g}$ tissue.

Triglycerides were estimated by the method of foster and Dunn [27]. To an aliquot of lipid extract, evaporated to dryness. $0.1 \mathrm{ml}$ of methanol was added followed by $4 \mathrm{ml}$ of isopropanol. $0.4 \mathrm{~g}$ of alumina was added to all the tubes and shaken well for $15 \mathrm{~min}$. Centrifuged and then 2 $\mathrm{ml}$ of the supernatant was transferred to labeled tubes. The tubes were placed in a water bath at $65^{\circ} \mathrm{C}$ for $15 \mathrm{~min}$ for saponification after adding $0.6 \mathrm{ml}$ of the saponification reagent followed by $0.5 \mathrm{ml}$ of acetyl acetone reagent. After mixing, the tubes were kept in a water bath at $65^{\circ} \mathrm{C}$ for $1 \mathrm{~h}$, the contents were cooled and absorbance was read at $420 \mathrm{~nm}$. The triglyceride content was expressed as $\mathrm{mg} /$ $100 \mathrm{~g}$ tissue.

Phospholipid content was determined by the method of Zilversmit et al [28]. To $0.1 \mathrm{ml}$ of lipid extract, added $1 \mathrm{ml}$ of $5 \mathrm{~N} \mathrm{H}_{2} \mathrm{SO}_{4}$ and $1 \mathrm{ml}$ of concentrated nitric acid and digested to a colourless solution. The phosphorus content in the extract was determined by the method of Fiske and Subba Row [29]. The values were expressed as g/100 g tissue. 
Table 2: Changes in blood glucose and plasma insulin levels of control and experimental animals

\begin{tabular}{|c|c|c|}
\hline Groups & fasting blood glucose (mg/dL) & Plasma insulin $(\mu \mathrm{U} / \mathrm{mL})$ \\
\hline Normal & $81.58 \pm 2.40^{\mathrm{a}}$ & $11.18 \pm 0.744^{a}$ \\
\hline Normal & $81.58 \pm 2.40^{a}$ & $11.18 \pm 0.74 \mathrm{a}$ \\
\hline Diabetic control & $265.00 \pm 24.40^{b}$ & $3.55 \pm 0.38 c$ \\
\hline Diabetic + Diasulin $(50$ mg/kg) & $210.80 \pm 14.26 c$ & $5.61 \pm 0.48^{d}$ \\
\hline Diabetic + Diasulin (100 mg/kg) & $158.33 \pm 11.00^{d}$ & $6.03 \pm 0.4 \mathrm{Id}^{\mathrm{d}}$ \\
\hline Diabetic + Diasulin (200 mg/kg) & $104.16 \pm 6.70 \mathrm{e}$ & $7.05 \pm 0.64 \mathrm{e}^{\mathrm{e}}$ \\
\hline Diabetic + Glibenclamide $(600 \mu \mathrm{g} / \mathrm{kg})$ & $1 \mid 1.60 \pm 9.86 \mathrm{e}$ & $6.32 \pm 0.55 \mathrm{de}$ \\
\hline
\end{tabular}

Values are given as mean \pm S.D for 6 rats in each group.

Values not sharing a common superscript letter differ significantly at $p<0.05$ (DMRT).

Duncan procedure, Range for the level 2.89, 3.03, 3.13, 3.20, 3.25.

Diabetic control was compared with normal, ${ }^{\dagger} p<0.001$.

Experimental groups were compared with diabetic control, $* p<0.001 .+++,>2 \%$ sugar, $++;-2 \%$ sugar;,$+-1 \%$

Table 3: Changes in levels of Tbars and hydroperoxides in liver and kidney of control and experimental animals

\begin{tabular}{|c|c|c|c|c|}
\hline \multirow[t]{2}{*}{ Groups } & \multicolumn{2}{|c|}{ TBARS (mM / I $00 \mathrm{~g}$ tissue) } & \multicolumn{2}{|c|}{ Hydro peroxide ( $\mathrm{mM} / \mathrm{l} 00 \mathrm{~g}$ tissue) } \\
\hline & Liver & Kidney & Liver & Kidney \\
\hline Normal & $0.73 \pm 0.066^{a}$ & $0.845 \pm 0.07 a$ & $71.42 \pm 4.6 \mathrm{I}^{\mathrm{a}}$ & $53.56 \pm 4.6 \mathrm{I}^{\mathrm{a}}$ \\
\hline Normal + Diasulin (200 mg/ kg) & $0.72 \pm 0.079 a$ & $0.785 \pm 0.065^{a}$ & $69.63 \pm 6.09 a$ & $52.40 \pm 3.90^{a}$ \\
\hline Diabetic control & $1.77 \pm 0.06^{b}$ & $1.565 \pm 0.105^{b}$ & $102.37 \pm\left. 6.4\right|^{b}$ & $75.35 \pm 4.46^{b}$ \\
\hline Diabetic + Diasulin (200 mg/kg) & $0.88 \pm 0.053^{c}$ & $0.970 \pm 0.072^{c}$ & $78.56 \pm 5.83^{c}$ & $61.89 \pm 6.07 c$ \\
\hline Diabetic + Glibenclamide $(600 \mu \mathrm{g} / \mathrm{kg})$ & $0.93 \pm 0.088 c$ & $1.00 \pm 0.086 c$ & $80.90 \pm 5.32^{c}$ & $63.16 \pm 6.30^{c}$ \\
\hline
\end{tabular}

Values are given as mean \pm S.D for 6 rats in each group.

Values not sharing a common superscript letter differ significantly at $p<0.05$ (DMRT).

Duncan procedure, Range for the level 2.95, 3.09, 3.20.

Free fatty acids were estimated by the method of Falholt et al [30]. $0.1 \mathrm{ml}$ of lipid extract was evaporated to dryness. $1 \mathrm{ml}$ of phosphate buffer, $6 \mathrm{ml}$ of extraction solvent and $2.5 \mathrm{ml}$ of copper reagent were added. All the tubes were shaken vigorously. $200 \mathrm{mg}$ of activated silicic acid was added and left aside for $30 \mathrm{~min}$. The tubes were centrifuged and $3 \mathrm{ml}$ of the copper layer was transferred to another tube containing $0.5 \mathrm{ml}$ of diphenyl carbazide and mixed carefully. The absorbance was read at $550 \mathrm{~nm}$ immediately. The amount of free fatty acids was expressed as $\mathrm{mg} / 100 \mathrm{~g}$ tissue.

\section{Statistical analysis}

The data for various biochemical parameters were analysed using analysis of variance (ANOVA) and the group means were compared by Duncan's Multiple Range Test (DMRT). Values were considered statistically significant when at $\mathrm{p}<0.05[31]$.

\section{Results}

Table 2 shows the level of blood glucose and plasma insulin in control and experimental animals. There was a significant elevation in blood glucose level with significant decrease in plasma insulin levels in alloxan diabetic rats, compared with normal rats. Administration of Diasulin and glibenclamide tended to bring blood glucose and plasma insulin towards near normal levels. The effect of Diasulin at $200 \mathrm{mg} / \mathrm{kg}$ was significantly better than 50 and $100 \mathrm{mg} / \mathrm{kg}$, therefore the higher dose was used for further biochemical studies. The administration of Diasulin and glibenclamide to normal rats showed a significant effect in lowering blood glucose and increasing plasma insulin.

Table 3 represents the concentration of TBARS and hydroperoxides in tissues of control and experimental animals. There was a significant elevation in tissue TBARS and hydroperoxides during diabetes, when compared to the corresponding control group. Administration of Diasulin and glibenclamide tends to bring the values to near normal.

Table 4 and 5 shows the levels of cholesterol, triglycerides, free fatty acids and phospholipids in liver and kidney of control and experimental rats respectively. Liver and kidney of diabetic rats showed significantly increased levels 
Table 4: Changes in levels of cholesterol, free fatty acids, triglycerides and phospholipids in liver of control and experimental animals

\begin{tabular}{|c|c|c|c|c|}
\hline Groups & $\begin{array}{c}\text { Cholesterol } \\
\text { (mg// } 00 \text { g wet tissue) }\end{array}$ & $\begin{array}{c}\text { Free fatty acids } \\
\text { (mg// } 00 \text { g wet tissue) }\end{array}$ & $\begin{array}{c}\text { Triglycerides } \\
\text { (mg//00 g wet tissue) }\end{array}$ & $\begin{array}{c}\text { Phospholipids } \\
\text { (mg// } 00 \text { g wet tissue) }\end{array}$ \\
\hline Normal & $328.90 \pm 18.90^{a}$ & $606.10 \pm 21.76^{a}$ & $344.50 \pm 23.20^{a}$ & $1598.00 \pm 19.30^{a}$ \\
\hline Normal + Diasulin (200 mg/ kg) & $321.25 \pm 5.74^{a}$ & $601.93 \pm 19.00 \mathrm{a}$ & $341.10 \pm 21.00 \mathrm{a}$ & $1593.10 \pm 24.10^{a}$ \\
\hline Diabetic control & $517.33 \pm 13.10^{b}$ & $921.60 \pm 44.60^{b}$ & $622.50 \pm 18.80^{b}$ & $1858.60 \pm 18.70^{b}$ \\
\hline Diabetic + Diasulin $(200 \mathrm{mg} / \mathrm{kg})$ & $421.75 \pm 17.54^{c}$ & $769.16 \pm 13.30 c$ & $456.25 \pm 17.30 c$ & $1718.80 \pm 14.40 c$ \\
\hline Diabetic + Glibenclamide $(600 \mu \mathrm{g} / \mathrm{kg})$ & $445.00 \pm 9.79 c$ & $802.80 \pm 53.77 c$ & $530.80 \pm 35.70^{d}$ & $1769.30 \pm 17.60 c$ \\
\hline
\end{tabular}

Values are given as mean \pm S.D for 6 rats in each group.

Values not sharing a common superscript letter differ significantly at $\mathrm{p}<0.05$ (DMRT).

Duncan procedure, Range for the level 2.95, 3.09, 3.20.

Table 5: Changes in levels of cholesterol, free fatty acids, triglycerides and phospholipids in kidney of control and experimental animals

\begin{tabular}{lcccc}
\hline \multicolumn{1}{c}{ Groups } & $\begin{array}{c}\text { Cholesterol } \\
\text { (mg// 00 g wet tissue) }\end{array}$ & $\begin{array}{c}\text { Free fatty acids } \\
(\mathbf{m g} / \mathbf{1 0 0} \text { g wet tissue) }\end{array}$ & $\begin{array}{c}\text { Triglycerides } \\
\text { (mg// 00 g wet tissue) }\end{array}$ & $\begin{array}{c}\text { Phospholipids } \\
\text { (mg// 00 g wet tissue) }\end{array}$ \\
\hline Normal & $375.90 \pm 16.58^{\mathrm{a}}$ & $434.01 \pm 11.50^{\mathrm{a}}$ & $282.50 \pm 14.70^{\mathrm{a}}$ & $1447.60 \pm 26.90^{\mathrm{a}}$ \\
Normal + Diasulin $(200 \mathrm{mg} / \mathrm{kg})$ & $371.08 \pm 8.28^{\mathrm{a}}$ & $432.5 \mathrm{I} \pm 11.60^{\mathrm{a}}$ & $278.75 \pm 14.60^{\mathrm{a}}$ & $1442.50 \pm 43.30^{\mathrm{a}}$ \\
Diabetic control & $546.90 \pm 23.80^{\mathrm{b}}$ & $743.00 \pm 25.70^{\mathrm{b}}$ & $501.10 \pm 34.10^{\mathrm{b}}$ & $2041.50 \pm 33.69 \mathrm{~b}$ \\
Diabetic + Diasulin $(200 \mathrm{mg} / \mathrm{kg})$ & $435.20 \pm 12.18^{\mathrm{c}}$ & $556.80 \pm 38.50^{\mathrm{c}}$ & $382.90 \pm 9.28^{\mathrm{c}}$ & $1684.00 \pm 28.80^{\mathrm{c}}$ \\
Diabetic + Glibenclamide $(600 \mu \mathrm{gg} / \mathrm{kg})$ & $449.90 \pm 13.49 \mathrm{c}$ & $600.30 \pm 33.40^{\mathrm{d}}$ & $438.66 \pm 39.30^{\mathrm{d}}$ & $1819.30 \pm 34.70^{\mathrm{d}}$
\end{tabular}

Values are given as mean \pm S.D for 6 rats in each group.

Values not sharing a common superscript letter differ significantly at $\mathrm{p}<0.05$ (DMRT).

Duncan procedure, Range for the level 2.95, 3.09, 3.20.

of cholesterol, triglycerides, free fatty acids and phospholipids, when compared with normal rats. In rats treated with Diasulin and glibenclamide there was a significant decrease in the content of cholesterol, triglycerides, free fatty acids and phospholipids in both the tissues, when compared with diabetic control rats.

\section{Discussion}

Diabetes mellitus is one of the most common chronic disease and is associated with hyperlipidemia and co-morbidities such as obesity, hypertension. Hyperlipidemia is a metabolic complications of both clinical and experimental diabetes [32]. Alloxan, a beta cytotoxin, induces "chemical diabetes" (alloxan diabetes) in a wide variety of animal species by damaging the insulin secreting pancreatic $\beta$-cell, resulting in a decrease in endogenous insulin release, which paves the ways for the decreased utilization of glucose by the tissues [33]. In our study, we have observed that Diasulin decreases blood glucose in alloxan diabetic rats. The possible mechanism of action of extract could be correlated with the reminiscent effect of the hypoglycemic sulphonylureas that promote insulin secretion by closure of $\mathrm{K}^{+}$-ATP channels, membrane depolarization and stimulation of $\mathrm{Ca}^{2+}$ influx, an initial key step in insulin secretion. In this context, number of other plants has also been reported to have antihyperglycemic and insulin stimulatory effects [34,35]. Like the plant extract, glibenclamide also produced significant reduction in blood glucose levels of alloxan diabetic rats. Since alloxan is known to destroy pancreatic $\beta$-cells, the present findings appear to be in consonance with the earlier suggestion of Jackson and Bressler [36] that sulphonylureas have extra- pancreatic antihyperglycemic mechanism of action secondary to their insulin secreting effect and the attendant glucose uptake into, and utilization by, the tissues.

Apart from the regulation of carbohydrate metabolism, insulin also plays an important role in the metabolism of lipids. Insulin is potent inhibitor of lipolysis. Since it inhibits the activity of the hormone sensitive lipases in adipose tissue and suppresses the release of free fatty acids [37]. During diabetes, enhanced activity of this enzyme increases lipolysis and releases more free fatty acids in to the circulation [38]. Increased fatty acids concentration also increases the $\beta$-oxidation of fatty acids, producing more acetyl CoA and cholesterol during diabetes. 
In normal condition, insulin increases the receptor-mediated removal of LDL-cholesterol and decreased activity of insulin during diabetes causes hypercholestrolemia. Hypercholestrolemia and hypertriglycridemia have been reported to occur in diabetic rats [39]. The increased concentration of cholesterol could result in a relative molecular ordering of the residual phospholipids resulting in a decrease in membrane fluidity [40]. The increased concentration of free fatty acids in liver and kidney may be due to lipid breakdown and this may cause increased generation of NADPH, which results in the activation of NADPH dependent microsomal lipid peroxidation. Liver and kidney phospholipids were increased in diabetic control rats. Phospholipids is present in cell membrane and make up vast majority of the surface lipoprotein forming a lipid bilayer that acts as an interface with both polar plasma environment and non-polar lipoprotein of lipoprotein core [41]. Phospholipids are vital part of biomembrane rich in PUFA, which are susceptible substrate for free radicals such as $\mathrm{O}_{2}{ }^{\bullet}$ and $\mathrm{OH}^{\bullet}$ radicals [42]. Increased phospholipids levels in tissues were reported by $[43,44]$ in streptozotocin diabetic rats. Administration of Diasulin decreased the levels of tissue free fatty acids and phospholipids.

Accumulation of triglycerides is one of the risk factors in Coronary Heart Disease (CHD). The significant increase in the level of triglycerides in liver and kidney of diabetic control rats may be due to the lack of insulin. Since under normal condition, insulin activates the enzyme lipoprotein lipase and hydrolysis triglycerides [45]. Diasulin reduces triglycerides in tissues of alloxan-induced diabetic rats and may prevent the progression of CHD.

The results show increased lipid peroxidation in the tissues (liver and kidney) of diabetic control group. Previous studies have reported that there was an increased lipid peroxidation in liver, kidney and brain of diabetic rats $[46,47]$. This may be because the tissues contain relatively high concentration of easily peroxidizable fatty acids. Liver during diabetes, showed a relatively severe impairment in antioxidant capacity than kidney. The kidney exhibits a characteristic pattern of changes during diabetes [48]. The increase in oxygen free radicals in diabetes could be primarily due to increase in blood glucose levels, which upon autoxidation generate free radicals and secondarily due to the effects of diabetogenic agent alloxan [49]. In diabetes, hypoinsulinaemia increases the activity of the enzyme, fatty acyl coenzyme, coenzyme A oxidase, which initiates $\beta$-oxidation of fatty acids resulting in lipid peroxidation [50,51] Increased lipid peroxidation impairs membrane functions by decreasing membrane fluidity, and changing the activity of membrane-bound enzymes [51]. Its products (lipid radicals and lipid peroxide) are harmful to the cells in the body and are associated with atherosclerosis and brain damage [51]. Administration of Diasulin and glibenclamide reduced the lipid peroxidative markers in liver and kidney tissues of diabetic rats. This indicates that Diasulin inhibit oxidative damage due to the antiperoxidative effect of ingredients present in Diasulin. This could be correlated with previous study that reported that Cassia auriculata [52,53], Syzigium cumini $[54,55]$ Tinospora cardifolia [56], and Scoparia dulcis [57] (ingredients of Diasulin) have antiperoxidative and antihyperlipidemic effect of diabetic animals.

Antidiabetic and antihyperlipidemic effect of Diasulin may be due to the effect of active constituents of different plants, viz, alkaloid and pectins from Coccinia indica [58] alkaloids from Tinospora cordifolia [59], emlicanin A and B from Emblica officinalis [60], trigonelline and scopoltin from Trigonella foenum graecum [61], alkaloid-6-methoxybenzoxazolinone and terpenoids such as scoparic acids A, B,C and scopadulcic acid A and B from 'scoparia dulcis' [62], which may be responsible for scavenging free radicals liberated by alloxan in diabetic rats.

On the basis of above results, it could be concluded that Diasulin, a combination of ten herbal plants exert a significant antihyperlipidemic and antiperoxidative effect. This could be due to different types of active principles, each with a single or a diverse range of biological activities, which serves as a good adjuvant in the present armamentarium of antidiabetic drug.

\section{Conclusion}

The liver and kidney exhibits numerous morphological and functional alterations during diabetes. Since both diabetes and hyperlipidemia are considered to be major risk factors for the premature atherosclerosis and essentially all the cholesterol in atherosclerotic plaques is derived from that of circulatory cholesterol. The antihyperlipidemic and antiperoxidative effect of Diasulin in particular could be considered as of possible therapeutic value.

\section{Competing interests}

The author(s) declare that they have no competing interests

\section{Authors' contributions}

LP - supervised the design and co-ordination of the study

RS - Practically conducted the design of the study and drafted the manuscript.

\section{References}

I. Scheen JA: Drug treatment of non- insulin dependent diabetes mellitus in the 1990s. Achievements and future development. Drug 1997, 54:355-368.

2. Sochar M, Baquer NZ, Mclean P: Glucose under utilization in diabetes. Comparative studies on the changes in the activities 
of enzymes of glucose metabolism in rat kidney and liver. Mol Physiol 1985, 7:5I-68.

3. Baynes JW, Thrope SR: Role of oxidative stress in diabetic complications. Diabetes 1999, 48: I-4.

4. Morel DW, Chisolm GM: Antioxidant treatment of diabetic rats inhibits lipoprotein oxidation and cytotoxicity. J Lipid Res 1989, 30:1827-1834.

5. Seifter S, England S: Energy metabolism. In The Liver; Biology and Pathology Edited by: Arias I, Papper M, Schacter D. New York, Reven Press; 1982:219-249.

6. Tiwari AK, Madhusudana Rao J: Diabetes mellitus and multiple therapeutic approaches of phytochemicals: Present status and future prospects. Curr Sci 2002, 83:30-38.

7. Bhattaram VA, Ceraefe M, Kohlest C, Vest M, Deundorf H: Pharmacokinetics and bioavailabitlity of herbal medicinal products. Phytomed 2002, 9:1-36.

8. Bailey C], Day C: Traditional treatments for diabetes. Diabetes Care 1989, I 2:553-564.

9. Mitra SK, Gopumadhavan S, Muralidhar TS, Anturlikar SD, Sujatha MB: Effect of a herbomineral preparation D-400 in streptozotocin induced diabetic rats. J Ethnopharmacol 1996, 54:41-46.

10. Annapurna A, Kanaka, Mahalakshmi D, Murali Krishna K: Antidiabetic activity of a polyherbal preparation (tincture of punchparna) in normal and diabetic rats. Indian J Exp Biol 200I, 39:500-502.

II. Bhattacharya SK, Satyan KS, Chakrbarti A: Effect of Trasina, an Ayurvedic herbal formulation, on pancreatic islet superoxide dismutase activity in hyperglycaemic rats. Indian J Exp Biol 1997, 35:297-299.

12. The WHO Expert Committee on Diabetes Mellitus. Technical Report Series 646, Geneva, and World Health Organisation 1980.

13. Jia W, Gao WY, Xiao PG: Antidaibetic drugs of plant origin used in China: Composition, pharmacology and hypoglycemic mechanisms. Zhongguo Zhong Yao Za Zhi 2003, 28:108-113.

14. Elder C: Ayurveda for diabetes mellitus: a review of the biomedical literature. Altern Ther Health Med 2004, 10:44-50.

15. Loew D, Kaszkin M: Approaching the problem of bioequivalence of Herbal Medicinal Products. Phytother Res 2002, 16:705-7|I.

16. Pari L, Ramakrishnan R, Venkateswaran S: Antihyperglycaemic effect of Diamed, an herbal formulation in experimental diabetes in rats. J Pharm Pharmacol 200I, 53: | |39-| | 43.

17. Pari L, Saravanan G: Antidiabetic effect of coagent db, a herbal drug in alloxan induced diabetes mellitus. Comp Biochem Physiol Part C 2002, 131:19-25.

18. Subash Babu P, Prince PSM: Antihyperglycemic and antioxidant effect of hyponidd an ayurvedic herbomineral formulation in streptozotocin induced diabetic rats. J Pharm Pharmacol 2004, 56: | $435-1442$

19. Pari L, Saravanan R: Antidiabetic effect of Diasulin, an herbal drug, on blood glucose, plasma insulin and hepatic enzymes of glucose metabolism in hyperglycemic rats. Diabetes Obes Metab 2004, 6:286-292.

20. Pandey VN, Rajagopalan SS, Chowdhorry DP: An effective ayurvedic hypoglycemic formulation. J Res Ayur Sid 1995 16:1-14.

21. Katsumata K, Katsumata y, Ozawa T, Katsumata K: Potentiating effects of combined usage of three sulfonylurea drugs on the occurrence of alloxan diabetic rats. Horm Metab Res 1999 , 25:125-126.

22. Folch J, Lees M, Solane SGH: A simple method for isolation and purification of total lipids from animal tissues. I Biol Chem 1957, 226:497-509.

23. Sasaki T, Matsy S, Sonae A: Effect of acetic acid concentration on the colour reaction in the O-toluidine boric acid method for blood glucose estimation. Rinshbokagaku 1972, I:346-353.

24. Niehius WG, Samuelsson D: Formation of Malondialdehyde from phospholipid arachidonate during microsomal lipidperoxidation. Eur J Biochem 1968, 6: 126-130.

25. Jiang ZY, Hunt JV, Wolft SD: Ferrous ion oxidation in the presence of xylenol orange for detection of lipid hydroperoxide in low density lipoprotein. Anal Biochem 1992, 202:384-389.

26. Zlatkis A, Zak B, Boyle Gl: A method for the determination of serum cholesterol. J Clin Med 1953, 41:486-492.
27. Foster JB, Dunn RT: Stable reagents for determination of serum triglyceride by colorimetric condensation method. Clin Chim Acta 1973, 19:338-340.

28. Zilversmit BB, Davis AK: Micro determination of plasma phospholipids by TCA precipitation. J Lab Clin Med 1950, 35: I55-160.

29. Fiske $\mathrm{CH}$, Subbarow J: The colorimetric determination of Phosphorus. J Biol Chem 1925, 66:375-400.

30. Falholt $K$, Falholt $W$, Lund $B$ : An assay colorimetric method for routine determination of free fatty acids in plasma. Clin Chim Acta 1973, 46: 105-III.

31. Duncan BD: Multiple range test for correlated and heteroscedastic means. Biometrics 1957, I3:359-364.

32. Bierman EL, Amaral JAP, Balknap BH: hyperlipidemia and diabetes mellitus. Diabetes 1975, 25:509-5I5.

33. Omamoto H, Ucgigata $\mathrm{Y}$, Hiroskitckan : STZ and alloxan induces DNA strand breaks and poly (ADPribose) synthatase in pancreatic islets. Nature 1981, 294:284-286.

34. Venkateswaran S, Pari L: Effect of Coccinia indica on blood glucose, insulin and hepatic key enzymes in experimental diabetes. Pharm Biol 2002, 40:165-170.

35. Latha M, Pari L: Antihyperglycaemic effect of Cassia auriculata in experimental diabetes and its effects on key metabolic enzymes involved in carbohydrate metabolism. Clin Exp Pharmacol Physiol 2003, 30:38-43.

36. Jackson JE, Bressler R: Clinical pharmacology of sulphonylurea hypoglycemic agents: part I. Drugs I98I, 22:2 I I-245.

37. Loci AS, Shaabha M, Khazraji AL, Husain A, Twaija A: Hypoglycemic effect of a valuable extract of artemicisia herb Alba II. Effect of a valuable extract on some blood parameters in diabetic animals. J Ethnopharmacol 1994, 43:167-I7I.

38. Agardh CD, Bjorgell P, Nilson EP: The effect of tolbutamide on lipoproteins, and lipoproteinlipase and hormone sensitive lipase. Diabetes Res Clin Pract 1999, 46:99-108.

39. Bopanna KN, Kannan J, Sushma G, Balaraman R, Rathod SP: Antidiabetic and antihyperlipidemic effect of neem seed, kernal powder on alloxan diabetic rabbits. Ind J Pharmacol 1997, 29:162-167.

40. Dario G, Antonio C, Giuseppe P: Oxidative stress and diabetic complications. Diabetes Care 1996, 19:257-267.

4I. Cohn RM, Roth KS: Lipid and lipoprotein metabolism. In Biochemistry and disease Williams and Wilkins Publishers, Baltimore; 1996:280.

42. Ahmed M, Shikha HA, Sadhu SK, Rahman MT, Datta BK: Diuretic, and anti-inflammatory principle from Scoparia dulcis. Pharmazie 200I, 56:657-660.

43. Venkateswaran S, Pari L, Saravanan G: Effect of Phaseolus vulgaris on circulatory antioxidants and lipids in streptozotocininduced diabetic rats. I Med Food 2002, 5:97-104.

44. Pari L, Amarnath satheesh M: Antidiabetic Effect of Boerhavia diffusa : Effect on Serum and Tissue Lipids in Experimental Diabetes. J Med Food 2004, 7:472-476.

45. Frayn KN: Insulin resistance and lipid metabolism. Curr Opin Lipidol 1993, 4:197-204.

46. Latha M, Pari L: Preventive effects of Cassia auriculata L. flowers on brain lipid peroxidation in rats treated with streptozotocin. Mol Cell Biochem 2003, 243:23-28.

47. Ananthan R, Latha M, Ramkumar KM, Pari L, Baskar C, Narmatha Bai V: Antidiabetic Effect of Gymnema montanum Leaves: Effect on lipid peroxidation induced Oxidative stress in experimental diabetes. Nutrition 2004, 6:379-386.

48. Aragno M, Tamagno E, Gatto $V$, Brignardello E, Parola S, Danni O Boccuzzi G: Dehydroepiandrosterone protects tissues of streptozotocin-treated rats against oxidative stress. Free Rad Biol Med 1999, 26: I 467-1474.

49. Szkudelski T: The mechanism of alloxan and streptozotocin action in b cells of the rat pancreas. Physiol Res 2001, 50:536-546.

50. Oberley LW: Free radicals and diabetes. Free Radic Biol Med 1988, 5:113-124.

5I. Baynes JW: Reactive oxygen in the aetiology and complications of diabetes. In Drug, Diet and Disease, Mechanistic Approach to Diabetes Volume 2. Edited by: loannides C, Flatt PR. Hertfordshive: Ellis Horwood limited; 1995:230-31.

52. Pari L, Latha M: Antidiabetic activity of Cassia auriculata flowers: Effect on lipidperoxidation in streptozotocin diabeties rats. Pharm Biol 2002, 40:5 I2-5I7. 
53. Pari L, Latha M: Effect of Cassia auriculata flowers on blood sugar levels, serum and tissue lipids in Streptoszotocin diabetic rats. Sing Med J 2002, 43:617-62I.

54. Prince PSM, Menon VP: Hypoglycemic activity of Syzigium cumini seeds; effect on lipid peroxidation in alloxan diabetic rats. J Ethnopharmcol 1998, 61:1-7.

55. Prince PSM, Kamalakkannan N, Menon VP: Antidiabetic and antihyperlipidaemic effect of alcoholic Syzigium cumini seeds in alloxan induced diabetic albino rats. J Ethnopharmacol 2004, 91:209-I3.

56. Prince PSM, Menon VP, Gunasekaran G: Hypolipidimic action of Tinnospora coradifolia root extract in alloxan diabetic rats. J Ethnopharmacol 1999, 14:4-16.

57. Latha M, Pari L: Modulatorry effect of Scoparia dulcis in oxidative stress-induced lipidperoxidation in streptozotocin diabetic rats. J Med Food 2003, 6:379-386.

58. Hossain MZ, Shibib BA, Rahman R: Hypoglycemic effect of coccinia indica; inhibition if key gluconeogenic enzyme, glugose6-phosphate. Indian J Biol 1992, 30:418-420.

59. Prince PSM, Menon VP, Pari L: Antioxidant action of Tinosfora cordifolia root extract in alloxan diabetic rats. Phytother Res 2002, I5:213-218.

60. Aruna Bhattacharya, chatterjee A, hosal S, Sail K: Antioxidant activity of active tannoid principles of Emblica officinalis (amala). Indian J Exp Biol 1999, 137:676-680.

61. Jachak Sanja M: Herbal drugs as antidiabetics. An overview. CRIPS 2002, 3:2.

62. Pari L, Latha L: Protective role of scopari dulcis plant extract on brain antioxidant status and lipidperoxidation in STZ diabetic male wistar rats. BMC Compliment Altern Med 2004, 4:16.

\section{Pre-publication history}

The pre-publication history for this paper can be accessed here:

http://www.biomedcentral.com/1472-6882/5/14/prepub

Publish with Biomed Central and every scientist can read your work free of charge

"BioMed Central will be the most significant development for disseminating the results of biomedical research in our lifetime. "

Sir Paul Nurse, Cancer Research UK

Your research papers will be:

- available free of charge to the entire biomedical community

- peer reviewed and published immediately upon acceptance

- cited in PubMed and archived on PubMed Central

- yours - you keep the copyright

Submit your manuscript here:

http://www.biomedcentral.com/info/publishing_adv.asp
BioMedcentral 